\title{
ANALISIS KESALAHAN BERBAHASA PRANCIS PEMANDU WISATA DI TANA TORAJA
}

\author{
Kidung Biantong Parura ${ }^{1}$, Fierenziana Getruida Junus ${ }^{2}$, Mardi Adi Armin ${ }^{3}$ \\ ${ }^{1,2,3}$ Fakultas Ilmu Budaya, Universitas Hasanuddin \\ kidungcelindo077@gmail.com \\ fierenziana@gmail.com \\ adiarmin@hotmail.com
}

\begin{abstract}
This article is the result of a study on "French Language Guide in Tana Toraja". This study aims to analyze the mistakes made by tour guides in Tana Toraja in French. The subjects in this study were 3 French-speaking tour guides, and the object in this study was a mistake in French. This study uses descriptive qualitative and quantitative analysis methods with a theory approach to analyzing language errors in the Tarigan model that divides language errors into misformation, omission, addition, and misorder which will then be searched for factors causing language errors by tour guides in Tana Toraja. After conducting research, the results of the analysis show that all tour guides make mistakes in French, and the most dominant tour guide makes mistakes is the tour guide 1 . The error is caused by performance factors such as experience and communication goals and competency factors, namely education.
\end{abstract}

Keywords: Error speaking, French Languange, Tour Guide

\section{PENDAHULUAN}

Bahasa merupakan alat atau sarana komunikasi yang digunakan antarmanusia. Bahasa dapat mengekpresikan maksud dan tujuan seseorang. Lewat bahasa pula kita dapat memahami serta berkomunikasi baik dengan sesama manusia. Maksudnya adalah sesuatu yang tidak jelas bisa menjadi lebih jelas karena bahasa. Dalam berbahasa, terdapat sesuatu yang direncanakan atau bahkan tidak direncanakan, bahkan kita harus mencatat sesuatu yang semestinya akan dibicarakan.

Kita ketahui bahwa sebagian besar penduduk di dunia adalah dwibahasawan, maksudnya bahwa sebagian manusia di bumi ini menggunakan dua bahasa atau lebih sebagai alat komunikasi. Seperti halnya seseorang yang bisa berkomunikasi dalam bahasa Prancis (BP) dan bahasa Indonesia (BI), inilah yang disebut dwibahasaan. Dari sisi tata bahasanya, BP dan BI sangat jauh berbeda. BP adalah bahasa aglutinatif yang mengenal adanya konjugasi verba, sedangkan BI adalah bahasa flektif yang tidak mengenal konjugasi verba.

Perbedaan antara BP dan BI mengakibatkan kesalahan bagi penggunanya, seperti pemandu wisata di Tana Toraja. Dasar dari penelitian ini adalah karena adanya keluhan dari turis kepada pemandu wisata, dalam hal ini sesekali turis meluruskan tuturan dari pemandu wisata. Dari penjelasan pemandu wisata, sering dijumpai kesalahan gramatikal, makna, dan bunyi. Kesalahankesalahan berbahasa tersebut terjadi misalnya pada saat seorang pemandu wisata bertanya kepada wisatawan " vous habitez ou en Francais ?" dari pertanyaan tersebut, jelas maknanya sangat jauh berbeda, seharusnya "vous habitez ou en France ?". Oleh karena itu masalah mengenai kesalahan berbahasa yang dilakukan oleh pemandu wisata di Tana Toraja menarik untuk diteliti. 


\section{TINJAUAN PUSTAKA Pengertian Bahasa}

Menurut Wardhaugh (2005) bahasa (language) merupakan sistem lambang bunyi yang arbitrer, yang dipergunakan oleh para anggota suatu masyarakat untuk bekerja sama, berinteraksi, dan mengidentifikasikan diri. Bahasa pun menjadi pusat pemahaman dan kesalahpaham manusia. Ferdinand de Saussure dalam Rosmanuddin (2009) membedakan antara yang disebut langage, langue, dan parole. Ketiga istilah yang berasal bahasa Prancis itu, dalam bahasa Indonesia secara tidak cermat, lazim, dipadankan dengan satu istilah, yaitu bahasa. Padahal ketiganya mempunyai pengertian yang sangat berbeda, meskipun ketiganya memang sama-sama bersangkutan dengan bahasa. Dalam bahasa Prancis istilah langage digunakan untuk menyebut bahasa sebagai sistem lambang bunyi yang digunakan manusia untuk berkomunikasi dan berinteraksi secara verbal di antara sesama. Langage bersifat abstrak. Barang kali istilah langage dapat dipadankan dengan kata bahasa seperti terdapat dalam kalimat "Manusia mempunyai bahasa, binatang tidak". Langue mengacu pada seistem lambang bunyi tententu yang digunakan oleh anggota masyarakat tertentu, dan parole merupakan pelaksana dari langue dalam bentuk ujaran atau tuturan yang dilakukan oleh para anggota masyarakat di dalam berinteraksi atau berkomunikasi sesamanya.

\section{Pemerolehan Bahasa Pertama}

Seorang anak yang normal pasti akan memperoleh dan belajar bahasa pertamanya. Bahasa pertama tersebut yang kemudian disebut Bahasa Ibu (B1). Biasanya seorang anak memperoleh bahasa pertamanya pada usia 1-5 tahun dalam lingkungan keluarga, kemudian dalam lingkungan masyarakat dan lingkungan sekolah. Menurut Subyakto (1988:73) pemerolehan Bahasa Pertama (B1) terjadi dalam keadaan seorang anak belum pernah belajar bahasa apapun, atau dengan kata lain mulai belajar bahasa untuk pertama kali. Anak tersebut, disebut ekabahasawan (monolingual).

\section{Pemerolehan Bahasa Kedua}

Yang dimaksud bahasa kedua (B2) adalah bahasa lain yang dipelajari setelah menguasai bahasa ibu sampai batas tertentu. Pateda (1990:99) menyamakan istilah bahasa kedua (second language) dengan bahasa asing (foreign language). Pemerolehan B2 secara terpimpin yaitu seorang siswa yang belajar bahasa kedua di sekolah, terdapat guru dengan materi dan metode yang telah ditentukan. Pemerolehan B2 seperti ini sangat tergantung dari guru sebagai pengajar dalam menentukan metode-metode yang sesuai bagi siswanya. Pemerolehan B2 secara alamiah yaitu pemerolehan B2 secara spontan yang terjadi dalam komunikasi sehari-hari, tanpa bimbingan seorang guru. Misalnya seseorang yang memperoleh B2 di negara asing yang memperoleh B2 dengan cara berinteraksi dengan penduduk asli.

\section{Kesalahan Berbahasa}

\section{a. Pengertian Kesalahan Berbahasa}

Menurut Tarigan (1988:272)

kesalahan merupakan sisi yang mempunyai cacat pada ujaran kata atau tulisan. Pateda (1990:38) menyatakan bahwa kesalahan berbahasa adalah penyimpanganpenyimpangan yang bersifat sistematis yang dilakukan peserta didik ketika sedang menggunakan bahasa. Kesalahan berbahasa tersebut disebut juga kegalatan. Berdasar atas kedua pendapat di atas, maka dapat disimpulkan bahwa kesalahan dalam berbahasa adalah penyimpangan yang dilakukan penutur bahasa dalam bertutur akibat kurangnya penguasaan kaidah kebahasaan yang digunakan.

b. Kesalahan Berbahasa Model Tarigan Dalam penuturan bahasa kedua (B2) setiap penutur pasti pernah melakukan kesalahan. Hal tersebut sudah 
biasa dan bukan merupakan suatu keanehan. Justru dari kesalahan yang dilakukan penutur tersebut, penutur harus melakukan suatu tindakan untuk meminimalkan kesalahannya agar penutur lebih baik dalam menuturkan bahasa keduanya. Hal itulah yang sering disebut analisis kesalahan bagi sebagian orang. (Tarigan, 1990:6) menyingkat analisis kesalahan menjadi anakes. Anakes adalah Pengkajian secara cermat dan mendalam tentang segala aspek kesalahan yang sering dibuat oleh penutur B2. Dalam penelitian ini, untuk menganalisis kesalahan, digunakan taksonomi strategi permukaan. Dengan taksonomi ini kesalahan gramatikal digolongkan berdasarkan pada bagaimana struktur bahasa mengalami perubahan yang mengarah pada kesalahan. Kesalahan yang mungkin terjadi adalah (1) omission, yakni penghilangan unsur-unsur kalimat tertentu yang justru diperlukan, (2) addition, yaitu penambahan unsur-unsur kata atau kalimat yang justru tidak diperlukan, (3) misformation, yakni pembentukan unsur kalimat yang salah yang dilihat dari aturan gramatikal bahasa, dan (4) misorder, yaitu kalimat yang samar - samar.

Kekeliruan dalam berbahasa disebabkan karena faktor performansi, sedangkan kesalahan berbahasa disebabkan faktor kompetensi. Faktor performansi meliputi keterbatasan ingatan atau kelupaan sehingga menyebabkan kekeliruan dalam melafalkan bunyi bahasa, kata, urutan kata, tekanan kata atau kalimat. Kekeliruan ini bersifat acak, maksudnya dapat terjadi pada berbagai tataran linguistik. Kekeliruan biasanya dapat diperbaiki sendiri oleh penutur, dan lebih memusatkan perhatian pada pembelajaran. Sedangkan kesalahan yang di sebabkan faktor kompetensi adalah kesalahan yang disebabkan penutur yang belum memahami sistem linguistik bahasa yang digunakannya. Kesalahan berbahasa akan sering terjadi apabila pemahaman penutur tentang sistem bahasa kurang. Kesalahan berbahasa dapat berlansung lama apabila tidak diperbaiki.

\section{METODE PENELITIAN Ancangan Penelitian}

Penelitian ini menggunakan
pendekatan kualitatif dan kuantitatif
deskriptif, karena data yang diperoleh
merupakan data deskriptif yang tidak
menggunakan kuantitas atau jumlah
persentase akan tetapi analisis datanya
menggunakan pendekatan kualitaif dan
kuantitaif yang menggunakan kuantitas
atau jumlah persentase. Partisipan yang
digunakan untuk pengambilan data dalam
penelitian ini yaitu 3 orang pemandu
wisata BP.
Populasi

Menurut Sugiono (2014:103) populasi adalah wilayah generalisasi yang terdiri atas objek atau subjek yang mempunyai kualitas dan karakteristik tertentu yang diterapkan oleh peneliti untuk mempelajari dan kemudian ditarik kesimpulannya.

Sampel

Sampel adalah sebagian anggota populasi yang diambil dengan menggunakan teknik tertentu yang disebut dengan teknik sampling. Sampel yang digunakan dalam penelitian ini diambil menggunakan teknik purposive sampling. Karena peneliti memerlukan pemandu wisata yang dapat mewakili karakteristik populasi, maka peneliti mengambil 3 (tiga ) orang pemandu wisata BP sebagai subjek penelitian karena kelas tersebut dianggap mampu mewakili karakteristik populasi yang diinginkan.

\section{HASIL DAN PEMBAHASAN Jenis-jenis Kesalahan}

a. Misformation

[...] Autrefois les Toraja gardent le buffle sur la maison [...] 
(Dahulu kala, orang Toraja menyimpan kerbaunya di bawah rumah)

Pada data di atas menit terjadi kesalahan pemilihan kala oleh responden dalam mengonjugasi verba garder ke dalam modus indikatif présent orang ketiga jamak menjadi gardent. Kalimat sebelumnya seharusnya dibuat dalam kala lampau, karena peristiwa tersebut terjadi pada masa lampau yang masih dilakukan sampai sekarang. Oleh karena itu verba garder seharusnya dikonjugasi ke dalam modus indikatif imparfait orang ketiga jamak menjadi gardaient. Kalimat yang seharusnya dituturkan responden adalah autrefois les Toraja gardaient le buffle sous la maison.

Kesalahan lain yang terjadi pada data di atas adalah pemilihan preposisi sur (di atas) yang seharusnya sous (di bawah), yang akan dibahas pada bagian lain.

\section{b. Omission}

[...]Pourquoi le sève comme lait pour le bébé[...]

(Mengapa getah dianggap sebagai susu untuk bayi)

Pada data di atas, makna kalimat yang dituturkan responden masih kurang tepat karena adanya penghilangan verba. Pada kalimat di atas, responden seharusnya menuturkan verba considerer yang dibentuk ke dalam diatesis pasif, karena kalimat pada data di atas merupakan kalimat pasif. Kalimat yang seharusnya dituturkan oleh responden adalah pourquoi la sève était considérée comme le lait par le bébé.

Kesalahan lain yang dilakukan responden pada data di atas adalah kesalahan pemilihan artikel yang akan dibahas pada bagian lain.

\section{c. Addition}

[...]Il faut que la maison traditionnelle orienter vers le nord pour respecter le créateur[...] (rumah tradisional menghadap ke Utara untuk menghormati sang pencipta)

Pada data di atas menit penuturan syntheme il faut que dapat mengubah makna kalimat menjadi nasihat atau konjugasi verba pada kalimat di atas harus dikonjugasi ke dalam modus subjonctif. Kesalahan penuturan syntheme pada kalimat di atas, seakan-akan menyatakan bahwa rumah tradisional di Toraja, dibangun tidak menghadap ke Utara karena sudah didahului oleh syntheme il faut que yang berarti seharusnya. Pada kalimat di atas, responden 1 tidak perlu menuturkan syntheme il faut que karena dapat mengubah makna kalimat, sehingga kalimat yang seharusnya dituturkan oleh responden adalah la maison traditionnelle oriente vers $\mathbf{d u}$ nord pour respecter le créateur.

Kesalahan lain yang terjadi pada data di atas adalah kesalahan pemilihan modus, dan kesalahan pemilihan artikel, yang akan dibahas pada bagian lain.

\section{d. Misorder}

[...]Autrefois, les Toraja pouvoir par rapport que maintenant [...]

(Dahulu kala, orang Toraja dapat bekerja bersama kerbau di sawah dibanding sekarang)

Pada data di atas, kalimat yang dituturkan responden adalah kalimat yang samar-samar atau kalimat yang maknanya tidak dapat dipahami dengan baik. Setelah melakukan hasil wawancara dengan responden, kalimat yang ingin dikatakan responden adalah "dahulu kala, orang Toraja dapat bekerja bersama kerbau di sawah dibanding sekarang". Kalimat yang seharusnya dituturkan responden dalam BP sehingga dapat dipahami dengan baik adalah autrefois, les Toraja pouvaient travailler dans la rizière avec le buffle par rapport que maintenant. Verba pouvoir pada kalimat di atas dalam modus infinitif présent yang seharusnya dikonjugasi ke dalam modus indikatif imparfait karena 
responden menceritakan peristiwa yang terjadi pada masa lampau, yang tidak segera berakhir pada saat itu.

Kesalahan lain yang terjadi pada data sebelumnya adalah penghilangan verba, penghilangan nomina, penghilangan adverbe, dan penghilangan preposisi, yang akan dibahas pada bagian lain.

\section{Faktor Penyebab Kesalahan}

\section{a. Faktor performansi (kekeliruan)}

Faktor performansi dalam kesalahan berbahasa, terjadi akibat keterbatasan ingatan dalam menuturkan bahasa. Dalam penelitian ini, responden sudah mempelajari sebagian dari sistem gramatikal BP, dan kosa kata dalam membentuk kalimat, akan tetapi responden tidak mengingat dengan baik mengenai aturan bahasa yang dituturkan sehingga menyebabkan kesalahan berbahasa. Kekeliruan dalam berbahasa disebabkan oleh faktor-faktor berikut:

- Pragmatis bahasa (tujuan komunikasi)

Kesalahan disebabkan karena di dalam menuturkan BP, tujuan utamanya yaitu agar wisatawan francophone dapat mengerti makna dari tuturan yang disampaikan oleh responden, jadi sistem gramatikal BP tidak terlalu diperhatikan karena yang terpenting bagaimana agar wisatawan mengerti dengan baik makna dari tuturan.

- Pengalaman

Kesalahan dalam berbahasa Prancis juga disebabkan oleh pengalaman (kebiasaan), karena penutur yang sudah lama tidak menuturkan BP, tidak mengingat dengan baik beberapa sistem gramatikal BP, sehingga dalam tuturannya akan menyebabkan kesalahan. R1, aktif menjadi pemandu wisata sejak tahun 19952010, dan tahun 2011-sekarang, R1 sudah tidak terlalu aktif menjadi seorang pemandu wisata, jadi R1 sudah jarang berkomunikasi dengan wisatawan francophone, sedangkan R2 dan R3 adalah pemandu wisata yang selalu aktif di tahun 2011-2019.

\section{b. Faktor kompetensi (kesalahan)}

Faktor kompetensi dalam kesalahan berbahasa, terjadi akibat penutur sama sekali tidak mengetahui sistem linguistik bahasa yang dituturkan, sehingga penutur melakukan kesalahan dalam berbahasa. Dalam hasil wawancara diketahui bahwa R1, R2, dan R3, mempelajari BP secara otodidak, bukan melalui pendidikan formal, sehingga masih ada sistem linguistik BP yang sama sekali tidak diketahui, seperti konjugasi verba ke dalam bentuk subjonctif dan conditionnel yang memang sama sekali tidak pernah dipelajari

\section{KESIMPULAN}

Berdasarkan hasil penelitian dan analisis data yang dilakukan mengenai kesalahan berbahasa Prancis pemandu wisata di Tana Toraja, dapat disimpulkan bahwa kesalahan berbahasa yang dilakukan oleh pemandu wisata di Tana Toraja adalah misformation (kesalahan gramatikal), omission (penghilangan unsur kata atau kalimat), addition (penambahan unsur kata atau kalimat), dan misorder (kalimat yang samar-samar). Kesalahan yang paling dominan dilakukan adalah kesalahan gramatikal, dan responden yang paling dominan melakukan kesalahan berbahasa adalah R1.Kesalahan berbahasa disebabkan oleh faktor performansi (kekeliruan) seperti pragmatis bahasa dan pengalaman serta faktor kompetensi (kesalahan) karena semua responden tidak mempelajari sistem gramatikal BP secara menyeluruh. Setelah melakukan wawancara singkat terhadap ketiga responden, diketahui bahwa R2 dan R3 adalah lulusan dari Fakultas Sastra Inggris dan R1 adalah lulusan dari fakultas FISIP. Kesalahan berbahasa yang dilakukan oleh para responden tidak memiliki pengaruh 
yang fatal karena wisatawan francophone dapat memahami tuturan responden.

\section{DAFTAR PUSTAKA}

Arafah, Burhanuddin \& Hasyim, Muhammad. 2019. Linguistic functions of emoji in social media communication. Opcion. 35 (24), 558-574.

Gita Putri Astari, Gita Putri, Hasyim, Muhammad, Kuswarini, Prasuri. 2019. Penerjemahan Metafora Novel "Lelaki Harimau” ke dalam "L'homme Tigre". Jurnal Ilmu Budaya. Vol 7 (1), 83-93.

Hasyim, Muhammad. 2015. Persepektif Semiotika atas Aspek Budaya dalam Penerjemahan Teks Kuliner Prancis. Prosiding Seminar Tahunan Linguistik, Bandung: Universitas Pendidikan Indonesia.

Newmark, P. (1988). A Textbook of Translation. Hertfordshire: Pearson Education Limited.

Pateda, M. 1990. Sosiolinguistik. Bandung: Angkasa.

Sugiono. 2014. Metode Penelitian Pendidikan. Bandung: Alfabeta.

Tarigan 1988. Pengajaran Pemerolehan Bahasa. Jakarta: Ditjen Pendidikan Tinggi.

Wardhaugh, Ronald. 2006. An Introduction to Sociolinguistics, New York: Wiley-Blackwell.

Rosmanuddin, S. A. 2009. Analisis Kesalahan Berbahasa. dalam https://Nahulinguistik.Wordpress. com/2009/05/29/AnalisisKesalahan-Berbahasa/ 